\title{
Pencatatan dan Pembukuan Via Aplikasi Akuntansi UMKM di Sidoarjo
}

\author{
Muhammad Agus Muljanto \\ Politeknik Keuangan Negara STAN \\ E-mail : agusmuljanto@pknstan.ac.id
}

DOI: https://doi.org/10.21107/pangabdhi.v6i1.6926

Naskah diterima 2 Februari 2020, Revisi 30 Maret 2020, Terbit 19 April 2020

\begin{abstract}
Abstrak
Permasalahan yang ditemukan adalah minimnya pengetahuan dan pemahaman mereka tentang akuntansi khususnya pencatatan dan pembukuan hingga penyusunan laporan keuangan. Pemahaman mereka sebelumnya bahwa pencatatan dan pembukuan itu sulit, merepotkan, dan menyita waktu menjadi penghambat untuk belajar akuntansi. Untuk itu pencatatan akuntansi berbasis teknologi menjadi penting terutama pada UMKM. Permasalahan yang dihadapi pelaku UMKM adalah belum adanya pelatihan pengelolaan keuangan usaha menggunakan aplikasi secara langsung. Solusi yang dibutuhkan adalah penyuluhan dan pendampingan bagi pelaku UMKM dalam mengelola keuangan menggunakan aplikasi akuntansi UMKM. Tujuannya agar pelaku UMKM mau dan disiplin menggunakan aplikasi akuntansi UMKM yang mudah digunakan secara mobile dengan media gadget dan sebagai upaya peningkatan kesadaran membayar pajak bagi pelaku UMKM. Pelaksanaan pengabdian masyarakat di Kantor Pelayanan Pajak Pratama Sidoarjo Selatan berjalan dengan baik dan dilaksanakan dengan 3 (tiga) metode. Peserta antusias dan bersemangat mengikuti kegiatan sampai selesai meskipun di awal pendampingan beberapa peserta mengalami kesulitan karena gaptek. Harapan kedepan agar pelaku UMKM di Sidoarjo Selatan mau dan disiplin untuk mencatat setiap aktivitas keuangan secara harian atau secara berkala dengan menggunakan aplikasi akuntansi UMKM dan patuh dalam melaporkan dan membayarkan pajaknya.
\end{abstract}

Kata kunci : UMKM, pengelolaan keuangan, aplikasi akuntansi, sadar pajak

\begin{abstract}
In South Sidoarjo, the MSME are engaged in various fields of the economy. The problem found is the lack of knowledge and understanding of accounting, especially recording and bookkeeping to the preparation of financial statements. Their previous understanding that recording and bookkeeping was difficult, troublesome, and time-consuming became a barrier to learning accounting. For this reason, technologybased accounting records are especially important at MSME. the problem faced by MSME is that there is no training in business financial management using applications directly. The solution needed is counseling and assistance for MSME in managing finances using the MSME accounting application. The goal is that MSME are willing and disciplined to use MSME accounting applications that are easy to use mobile with gadget media and as an effort to increase awareness of paying taxes for MSME. The implementation of community service at the South Sidoarjo Primary Tax Service Office went well and carried out with 3 (three) methods. Participants were enthusiastic and eager to follow the activity to the end even though at the beginning of the mentoring some participants experienced difficulties because they were catchy. Hopefully in the future, MSME in South Sidoarjo are willing and disciplined to record every financial activity on a daily or periodic basis using the MSME accounting application and to be obedient in reporting and paying their taxes.
\end{abstract}

Key Words : MSME, financial management, accounting applications, tax conscious

\section{PENDAHULUAN}

Usaha Mikro Kecil dan Menengah (UMKM) memiliki peran vital dan strategis dalam pembangunan ekonomi nasional. UMKM adalah salah satu pelaku kunci dalam proses pembangunan nasional. UMKM berperan penting dalam pertumbuhan perekonomian negara dan penyerapan tenaga kerja.

Menurut Kementerian Koperasi dan Usaha Kecil dan Menengah bahwa persentase sumbangan UMKM terhadap PDB dari tahun 2010 sampai dengan 2018 menunjukkan 
fluktuasi dan cenderung meningkat di tahun 2018. Di tahun 2010 sumbangan UMKM terhadap PDB sebesar 58,05\%; di tahun 2011 menurun menjadi 57,83\%; lalu di tahun 2012 menurun sedikit menjadi 57,6\%; tahun 2013 menjadi $57,48 \%$, tahun 2014 sedikit meningkat menjadi $57,56 \%$ dan meningkat lagi menjadi 57,75\% di tahun 2015; lalu di tahun 2016 turun menjadi $57,17 \%$ dan kembali turun menjadi 57,08\% di tahun 2017; akhirnya di tahun 2018 kontribusi UMKM terhadap PDB meningkat menjadi $60,34 \%$.

Sayangnya, sumbangan UMKM bagi perekonomian nasional tidak diimbangi dengan dukungan akses keuangan yang baik. Minimnya akses ke layanan keuangan dan rendahnya literasi keuangan ikut menghambat perkembangan UMKM di Indonesia. Menurut Otoritas Jasa Keuangan, hingga akhir bulan Februari 2016, pinjaman dalam negeri untuk UMKM hanya sebesar Rp728,97triliun, atau $18 \%$, jika dibandingkan dengan total kredit sebesar Rp3.998.09 triliun.

Pelaku UMKM di Indonesia sebenarnya memiliki potensi usaha yang besar disamping feasible dan suistainable. Namun sayangnya pelaku UMKM umumnya kurang aware dan tidak menganggap penting peran pencatatan dan pembukuan dalam usahanya, dibandingkan dengan aktivitas mereka menangani langsung usaha produksi dan penjualan/pemasaran.

Pembukuan berfungsi menyediakan informasi yang bersifat keuangan untuk pengambilan keputusan ekonomi (Sugiri dan Riyono, 2011). Penyusunan pembukuan tentunya melalui tahapan pencatatan yang dikenal sebagai siklus akuntansi. Pencatatan keuangan yang dilakukan UMKM seringkali hanya sebatas mencatat jumlah pengeluaran dan pemasukan keuangan secara sederhana. Hal ini belum dapat menjadi sumber informasi untuk pengambilan keputusan terkait operasionalisasi usaha tersebut.

Dengan demikian pengelolaan keuangan semisal penggunaan akuntansi berperan penting bagi perkembangan UMKM. Akuntansi adalah proses sistematis untuk menghasilkan informasi keuangan yang dapat digunakan untuk pengambilan keputusan bagi penggunanya. Kemanfaatan akuntansi bagi pelaku UMKM antara lain : (1) kinerja keuangan UMKM dapat mudah diketahui, (2) UMKM dapat mengetahui, memilah, dan membedakan harta perusahaan dan harta pemilik, (3) Posisi dana baik sumber maupun penggunaannya dapat segera diketahui, (4) penyusunan anggaran UMKM secara tepat,
(5) UMKM dapat menghitung pajak, dan (6) aliran uang tunai dalam periode tertentu dapat diketahui. Disamping itu dalam rangka mengenalkan ketentuan perpajakan khususnya Pajak Penghasilan (PPh) bagi UMKM penting untuk digalakkan kembali, mengingat UMKM belum memberikan kontribusi yang signifikan terhadap penerimaan negara berupa pajak. Menurut Endrianto (2015) UMKM mendominasi struktur usaha yang ada di Indonesia sekitar $99,99 \%$, yang terdiri dari usaha mikro $98,79 \%$, usaha kecil sebesar $1,11 \%$, usaha menengah sebesar $0,09 \%$. Sedangkan Usaha besar hanya berkontribusi dalam struktur usaha di

Indonesia sebesar $0,01 \%$. Lanjut Endrianto (2015) bahwa data menunjukkan sebagian besar penerimaan pajak didominasi oleh wajib pajak besar yang jumlahnya kurang dari 1\%. Beberapa penyebabnya adalah fakta bahwa Direktorat Jendral Pajak (DJP) lebih fokus pada wajib pajak besar sedangkan pengawasan kepada pelaku UMKM belum secara optimal dilakukan dan kepatuhan pajak pelaku UMKM juga masih rendah.

Ketentuan PPh bagi UMKM diatur dalam Peraturan Pemerintah Nomor 46 Tahun 2013 tentang Pajak Penghasilan Atas Penghasilan Dari Usaha yang Diterima atau Diperoleh Wajib Pajak yang Memiliki Peredaran Bruto Tertentu, Peredaran Bruto Tertentu menurut Pasal 3 adalah peredaran bruto setiap bulan atas penghasilan dari usaha Wajib Pajak tidak melebihi Rp 4,8 Miliar dalam satu tahun, maka UMKM dikenakan Pajak Penghasilan yang bersifat final sebesar $1 \%$, yang kemudian tarifnya diturunkan menjadi 0,5\% per 1 Juli 2018.

Sementara itu, menurut Achadiyah (2019) pencatatan akuntansi berbasis teknologi masih sangat jarang ditemui, terutama pada kegiatan usaha yang berskala menengah ke bawah atau yang sering disebut Usaha Mikro, Kecil, dan Menengah (UMKM). Padahal, penggunaan teknologi dapat membantu para pelaku UMKM yang memiliki keterbatasan ilmu akuntansi, sehingga mereka tidak perlu mempelajari tahapan demi tahapan siklus akuntansi manual yang dirasa rumit.

Sehubungan dengan penjelasan diatas, untuk itu di Sidoarjo telah dilakukan kegiatan pengabdian masyarakat bagi pelaku UMKM berupa penyuluhan dan pendampingan via aplikasi Akuntansi UMKM yang bisa diunduh secara gratis melalui playstore pada smartphone berbasis android dan dijalankan dengan media mobile handphone. Tujuannya agar pelaku 
UMKM mau dan disiplin menggunakan aplikasi akuntansi UMKM yang mudah digunakan dan sebagai upaya peningkatan kesadaran membayar pajak bagi pelaku UMKM.

Keunggulan aplikasi akuntansi UMKM ini adalah pelaku UMKM yang menggunakannya tinggal tekan tombol klik di gadget, tidak perlu jago akuntansi untuk mengerjakannya, dan tidak usah pusing memikirkan debit-kredit dalam pembukuan serta bisa dilakukan secara mobile kapanpun dan dimanapun berada.dengan gadget dalam genggaman.

\section{METODE}

Lokasi pelaksanaan kegiatan pengabdian masyarakat bertempat di Kantor Pelayanan Pajak Pratama Sidoarjo Selatan dan peserta sebanyak 51 (lima puluh satu) pelaku UMKM dalam bidang usaha makan minuman, makanan olahan, kriya, craft, tas koper (Intako Tanggulangin), dan usaha jasa di wilayah binaan Kantor Pelayanan Pajak Pratama Sidoarjo Selatan. Pelaksanaan dengan tatap muka langsung dalam bentuk sosialisasi via bahan tayang, pelatihan dengan bahan simulasi dan lembar latihan soal serta pendampingan penggunaan handphone kepada peserta sebagai media pencatatan dan pembukuan akuntansi via aplikasi disertai simulasi dan soal latihan akuntansi untuk dicatat dan dibukukan dalam handphone masing-masing peserta. Untuk mencapai tujuan sebagaimana tersebut di atas, maka kegiatan pengabdian masyarakat ini dilaksanakan dalam 3 (tiga) hari dengan metode berikut:

1. Metode Ceramah : penjelasan secara umum hal akuntansi; penghitungan Harga Pokok Produksi (HPP), Break Even Point (BEP) dan target penjualan; menentukan harga produk (pricing) dan PPh bagi UMKM. Pelaksanaan pada hari ke-1 selama 2 jam.

2. Metode Tutorial : Peserta pelatihan diberikan penjelasan tentang definisi dan contoh dari pengelompokan transaksi usaha (seperti : pemasukan, pengeluaran, hutang, bayar hutang, piutang, diterima piutang, tambah modal, tarik modal, pengalihan aset, dan penyesuaian), lalu simulasi aplikasi akuntansi UKM selanjutnya peserta mengerjakan latihan soal akuntansi UMKM. Peserta hanya cukup dengan mencatat keuangan usaha melalui input transaksi usaha pada menumenu yang sudah disediakan. Selanjutnya secara otomatis aplikasi akuntansi UMKM akan menyusun laporan keuangannya.
Langkah kedua diselenggarakan pada hari ke1 selama 6 jam.

3. Metode pendampingan : Peserta pelatihan diberikan kesempatan untuk mendiskusikan permasalahan yang berkaitan dengan keuangan UMKM yang selama ini dihadapi dan penggunaan aplikasi akuntansi UMKM untuk merekam/mencatat keuangan usahanya. Langkah ketiga diselenggarakan selama 8 jam dalam 2 hari (hari ke-2 dan hari ke- 3 ).

\section{HASIL DAN PEMBAHASAN}

Peserta dalam pelaksanaan pencatatan dan pembukuan dengan aplikasi Akuntansi UMKM diawali dengan melakukan persiapan penggunaan aplikasi akuntansi UMKM dengan terlebih dahulu menginstal aplikasi yang dapat diunduh dari playstore sebagaimana Gambar 1 berikut :

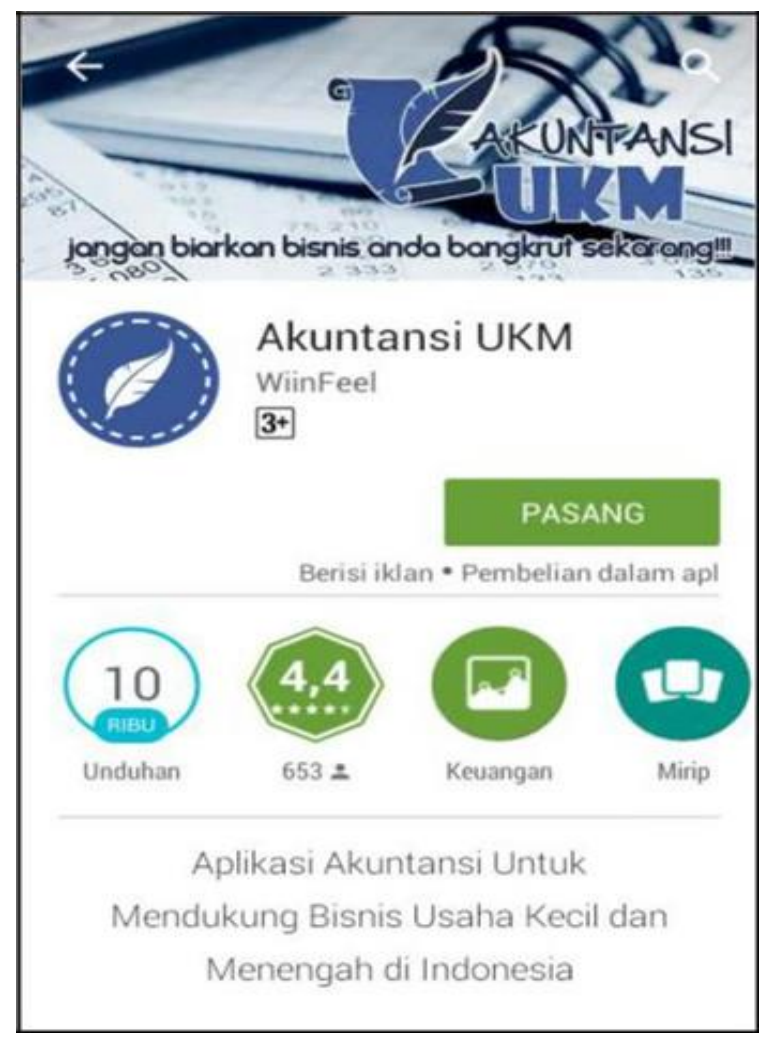

Gambar 1. Aplikasi Akuntansi UMKM

Peserta kemudian diminta mengisi profil data perusahaan masing-masing, selanjutnya peserta mempelajari dan memahami tentang pendefinisan dan contoh dari pengelompokan transaksi usaha yang kemudian dilanjutkan oleh semua peserta dengan mengerjakan latihan soal dan menginput transaksi keuangan dalam aplikasi tersebut. 
Aktivitas pembukuan semisal aktivitas memulai usaha (investasi awal), transaksi pembelian bahan baku, pemasukan/ penerimaan, pembelanjaan /pengeluaran, penjualan secara kredit, menerima pembayaran piutang penjualan, dan seterusnya. Transaksi-transaksi tersebut harus dibukukan secara teratur per hari sampai tersesuaikan saldonya sampai dengan akhir bulan, sehingga dapat diidentifikasi besaran margin atau laba yang dihasilkan per bulannya.

Bilamana diperoleh keuntungan dari usahanya, maka pelaku UMKM melaporkan dan membayar Pajak Penghasilan dengan tarif 0,5 persen. Sebagian besar peserta yang hadir belum memahami akuntansi dan menyadari pentingnya mencatat dan membukukan usaha sehari-hari, manfaat laporan keuangan dan rendahnya kepatuhan dalam pelaporan perpajakan. Peserta menganggap bahwa membukukan dan memahami debit kredit pada jurnal akuntansi adalah pekerjaan yang sulit, merepotkan, dan menyita waktu mereka. Dengan penggunaan aplikasi akuntansi UMKM ini peserta antusias dan bersemangat untuk mengikuti penyuluhan dan pendampingan sampai selesai meskipun di awal pendampingan beberapa peserta mengalami kesulitan karena gaptek. Dengan penggunaan aplikasi akuntansi UMKM ini peserta merasakan kemanfaatan yang mereka peroleh untuk dipergunakan dalam menjalankan usahanya, karena peserta terbantu dalam perhitungan keuangan usahanya secara tepat, membuat laporan keuangan usaha dengan mudah dan penyajian laporan keuangan secara cepat, yang memudahkan mereka dalam pengambilan keputusan keuangan dan pengembangan usahanya.

\section{KESIMPULAN}

Kegiatan penyuluhan dan pendampingan dalam pengabdian masyarakat ini ikut berkontribusi dalam menambah pengetahuan dan pemahaman dari peserta yang rata-rata tidak memahami akuntansi, terkait penggunaan aplikasi akuntansi UMKM selama 3 hari berturut-turut tersebut pada tanggal 22 Juli 2019 sampai dengan 24 Juli 2019 di Kantor Pelayanan Pajak Pratama Sidoarjo Selatan. Kegiatan penyuluhan dan pendampingan tersebut telah dilaksanakan dengan baik dan disambut dengan penuh antusias mengingat aplikasi akuntansi UMKM ini memiliki kelebihan karena bisa digunakan secara mobile dengan media gadget yang memberikan kemudahan dan kemanfaatan besar bagi pelaku UMKM dalam menjalankan usahanya. Harapannya agar pelaku UMKM di Sidoarjo Selatan yang telah mengikuti penyuluhan dan pendampingan tersebut mau dan disiplin untuk mencatat setiap aktivitas keuangan secara harian atau secara berkala dengan menggunakan aplikasi akuntansi UMKM ini untuk dapat merasakan kemanfaatan secara optimal dalam rangka pengambilan keputusan keuangan dan pengembangan usahanya. Hal ini sejalan dengan misi kantor pajak yang membina para pelaku UMKM dalam pengembangan usahanya dan mewujudkan kepatuhan dalam melaporkan dan membayarkan pajak.

\section{DAFTAR PUSTAKA}

Achadiyah, B,N. 2019. Otomatisasi Pencatatan Akuntansi Pada UMKM. Jurnal Akuntansi Multiparadigma JAMAL Vol 10. No 1. 188-206 pp.

Endrianto, W. 2015. Prinsip Keadilan Dalam Pajak Atas UMKM. Jurnal Binus Business Review Vol. 6 No 2. 298-308 pp.

Sugiri, S \& Riyono, B.A 2011. Akuntansi. Yogyakarta: UPP STIM YKPN. 